\title{
ANALISIS TINGKAT KEGEMPAAN WILAYAH JAWA TIMUR BERBASIS DISTRIBUSI SPASIAL DAN TEMPORAL MAGNITUDE OF COMPLETENESS (Mc), A-VALUE DAN B-VALUE.
}

\author{
Uswatun Chasanah ${ }^{1, *}$, Eko Handoyo ${ }^{2}$ \\ ${ }^{1}$ Prodi S1 Fisika, Universitas Muhammadiyah Lamongan, Lamongan \\ ${ }^{2}$ Prodi S1 Teknik Komputer, Universitas Muhammadiyah Lamongan, Lamongan \\ *uswah23@gmail.com
}

Received 25-11-2020, Revised 01-09-2021, Accepted 07-09-2021, Published 1-10-2021

\begin{abstract}
The Space and temporal distribution of the seismicity parameters consisting of magnitude of completeness (Mc), a-value, and b-value were estimated for the East Java, Indonesia using the International Seismological Center (ISC) earthquake catalogue. The main purposes of this research were to determine the parameters of the seismicity and its spatial temporal distribution so that early detection and warning systems in the East Java run optimally. All estimated parameters were analyzed based on an earthquake catalogue during 1980-2020 by applying The Maximum Curvature (MaxC) method. The MaxC method enumerate the highest value of the first subordinate of the cumulative Frequency Magnitude Distribution (FMD) graph. The value of the magnitude of completeness, which was estimated on this study as result Mc 3,4-4,8; a-value 5,560 - 8,244; and b-value (0,73-0,82 \pm 0.13$)$. The lower b-value $(0,73 \pm 0.13)$ was obtained for the southern part of the East Java. This area is indicated to have high seismic moment release and rock stress level accumulation. Understanding and clarifying the relation between seismicity parameters and structure of tectonic framework can guidance us to estimate seismic risk for earthquake hazard mitigation in the East Java.
\end{abstract}

Keywords: seismicity, magnitude of completeness, East Java.

\section{ABSTRAK}

Distribusi spasial dan temporal dari parameter seismisitas yang terdiri dari magnitude of completeness (Mc), a-value, dan b-value telah dihitung sebagai upaya untuk menganalisis tingkat kegempaan wilayah Jawa Timur. Parameter tersebut dihitung berdasarkan data katalog gempa bumi International Seismological Center (ISC) dalam rentang waktu antara tahun 1980-2020. Tujuan dari penelitian iniadalah untuk menentukan parameter seismisitas dan distribusi spasial dan temporalnya sehingga proses deteksi dan peringatan dini gempa bumi di Jawa Timur dapat berjalan secara optimal. Parameter seismistas dihitung dengan menggunakan metode Maximum Curvature (MaxC). Metode MaxC dalam menentukan parameter seismisitas terdiri dari proses menentukan titik kelengkungan maksimum dengan menghitung nilai maksimum dari turunan pertama kurva distribusi Frekuensi-Magnitudo (FMD). Variasi parameter seismisitas kemudian dipetakan secara spasial dan temporal setiap sepuluh tahun dalam kurun waktu 50 tahun terakhir untuk melihat perubahan variasi parameter seismisitas. Hasil penelitian menunjukkan Mc-value 3,4 - 4,8; a-value 5,560 - 8,244; dan bvalue $(0,73-0,82 \pm 0.13)$. Daerah yang memiliki $b$-value rendah $(0,73 \pm 0.13)$ berada di sekitar wilayah selatandai Jawa Timur. Wilayah ini diindikasikan sebagai daerah dengan pelepasan momen seismik yang tinggi dan memiliki akumulasi tingkat stress batuan yang tinggi. Mengetahui dan memahami hubungan antara parameter seismistas dan struktur tektonik dapat membantu kita untuk menentukan tingkat resiko bencana gempa bumi di wilayah Jawa Timur. 


\section{PENDAHULUAN}

Aktivitas kegempaan di Pulau Jawa, khususnya wilayah Jawa Timur tidak terlepas dari letaknya yang berada pada jalur zona subduksi antara lempeng Indo-Australia dan lempeng Eurasia yang membentang sepanjang pulau Jawa dan pulau Sumatra [1], [2]. Lempeng Indo-Australia menyusup kearah timur laut di bagian bawah lempeng Eurasia dengan kecepatan bervariasi disetiap titik, dari $63 \mathrm{~mm} /$ tahun di selatan Pulau Sumatra dan Jawa, $54 \mathrm{~mm} /$ tahun di utara Pulau Sumatra dan Jawa, dan $39 \mathrm{~mm} /$ tahun di sekitar lepas pantai Pulau Andaman [2], [3]. Dinamika geologi dari patahan aktif di sekitar Sunda dan Java trench tersebut berimplikasi pada seringnya terjadi gempa bumi di Jawa Timur kususnya di sepanjang lepas pantai selatan wilayah Jawa Timur ${ }^{[4], ~[5] . ~}$

Sementara itu, terdapat tiga segmentasi patahan yang berpotensi besar menyebabkan gempa bumi pada wilayah Jawa Timur yaitu patahan Kendeng, patahan Montong, dan patahan Wongsorejo ${ }^{[6]}$. Daerah perpotongan atau persinggungan diantara patahan perlu mendapat perhatian khusus dan harus diwaspadai, karena pada daerah ini gempa bumi terus bermunculan dan berpotensi menimbulkan bencana gempa bumi. Berdasarkan data Incorporated Research Institutions for Seismology (IRIS) di wilayah Jawa Timur dengan koordinat $6,09^{\circ}-9,57^{\circ}$ LS dan $110,92^{\circ}-114,52^{\circ}$ BT 776 kejadian gempa bumi terekam oleh jaringan seismograf dengan magnitudo antara 3-10 SR dan dengan kedalaman yang bervariasi 0-100 km. Beberapa gempabumi besar pernah terjadi di wilayah penelitan, yaitu gempa bumi dengan kekuatan 7,9 Mw pada tahun 1994 dan gempa bumi dengan kekuatan 7,8 Mw pada tahun 2006 (Gambar 1). Kedua gempa bumi tersebut meyebabkan Tsunami di pulau Jawa dengan gelombang setinggi $13 \mathrm{~m}$ dan $8 \mathrm{~m}$, dan menyebabkan kerusakan yang siginifikan dengan jumlah korban jiwa kurang lebih 600 jiwa ${ }^{[7],[8]}$.

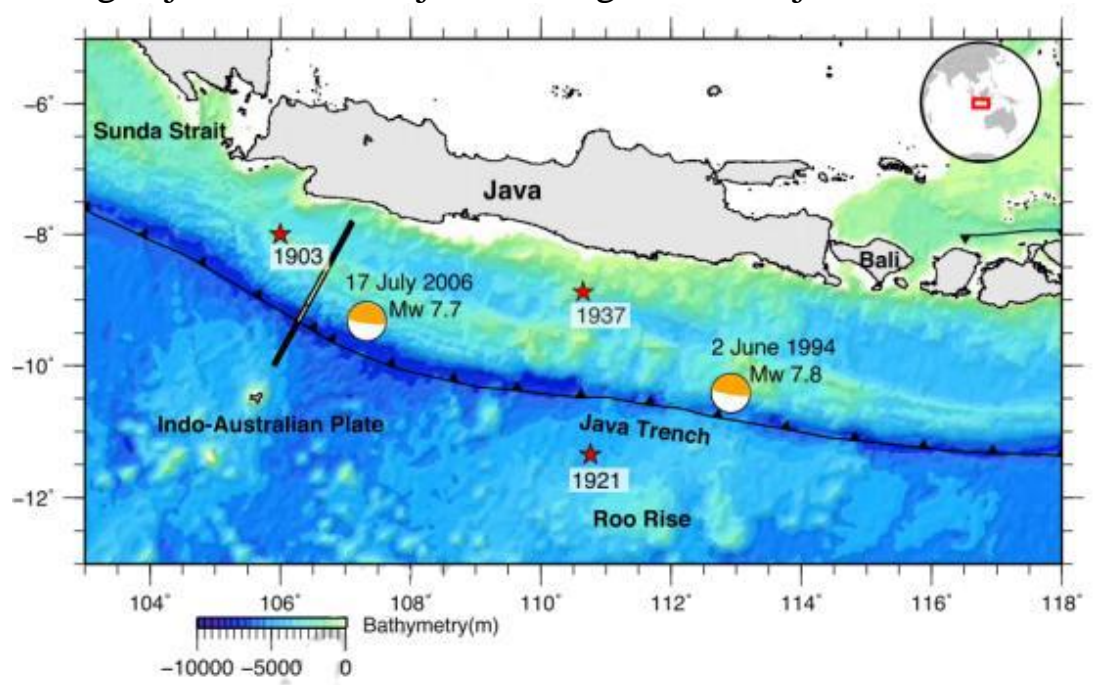

Gambar 1. Dua gempa bumi besar yang telah terekam oleh jaringan seismograf digital di sekitar pulau Jawa $^{[8]}$

Berdasarkan data-data sejarah gempa bumi yang pernah terjadi di sekitar wilayah Jawa Timur, maka perlu dilakukan suatu kajian mendasar mengenai akivitas kegempaan atau seismisitas yang berbasis sejarah gempa bumi. Seismisitas dapat mengindikasikan karakteristik dan aktivitas tektonik antar lempeng maupun di dalam lempeng (intraplate). Seismisitas dapat diartikan sebagai besaran yang terukur untuk membandingkan aktivitas seismik atau kegempaan antara satu daerah dengan daerah lain. Di dalam seismisitas terdapat parameter-parameter sebagai ukuran tingkat kegempaan suatu wilayah, yaitu parameter keaktifan seismik (a-value), tingkat stress batuan (b-value), dan kelengkapan 
magnitudo terendah yang terekam oleh jaringan seismogram atau disebut magnitude of completeness $(\mathrm{Mc})$.

Penelitian tentang seismisitas di wilayah Jawa Timur sebelumnya telah dilakukan oleh beberapa peneliti Shohaya dkk (2013) dan Mutiarani (2013) $)^{[4,5]}$. Namun, hanya gempa bumi yang relatif besar yang digunakan sebagai objek penelitian, sedangkan gempa bumigempa bumi kecil dan analisis statistiknya belum diperhatikan. Pada penelitian tersebut juga disimpulkan bahwa Jawa Timur memiliki tingkat heterogenitas batuan yang rendah berdasarkan variasi $a$-value dan $b$-value. Untuk melengkapi penelitian sebelumnya, pada penelitian ini dilakukan analisis gempa bumi-gempa bumi kecil sehingga diperoleh parameter kelengkapan magnitudo terkecil yang terekam oleh jaringan seismogram (Mcvalue).

Dengan ketersediaan data seismik di daerah penelitian, distribusi spasial dan temporal berdasarkan variasi $a$-value, $b$-value dan Mc-value diteliti. Tujuan utamanya adalah untuk mengilustrasikan hal-hal berikut: (a) karakteristik seismisitas wilayah Jawa Timur berdasarkan korelasi antara a-value, b-value dan Mc-value (b) aktivitas kegempaan di wilayah penelitian.

\section{METODE}

Penelitian ini menggunakan data katalog gempa bumi dari ISC di wilayah Jawa Timur yang berada di koordinat $6,09^{\circ}-9,57^{\circ}$ LS dan $110,92^{\circ}-114,52^{\circ}$ BT, yang memuat informasi gempa bumi yang telah terjadi di wilayah tersebut antara tahun 1980 sampai dengan tahun 2020 pada kedalaman kurang dari $300 \mathrm{~km}$ dari permukaan bumi. Lebih dari 2.685 gempa bumi yang terekam oleh jaringan seismograf digital pada periode 1990-2020 yang terjadi di wilayah Jawa Timur. Terdapat banyak kejadian gempa bumi pada katalog tersebut yang tidak memeliki atribut lengkap, sebagai contoh tidak terdapatnya data magnitudo dalam katalog. Sehingga data kejadian gempa bumi terebut tidak dapat digunakan sebagai katalog yang akan digunakan dalam penelitian ini.

Apabila kita akan menggunakan katalog gempa bumi yang tidak lengkap atributnya, langkah awal yang harus dilakukan yaitu mengkonversi seluruh magnitudo menjadi satu jenis magnitudo momen (Mw). Setelah proses konversi satuan magnitudo, kemudian data katalog gempa bumi tersebut diidentifikasi dan dipisahkan antara gempa bumi utamanya terhadap gempa bumi awalan dan gempa bumi susulan, proses ini umunya disebut sebagai proses dekluster katalog gempa bumi. Gempa bumi utama dipisahkan dari gempa bumi awalan dan susulan berdasarkan algoritma yang dikembangkan oleh Reasenberg (1985) ${ }^{[9]-}$ [12]. Algoritma yang digunakan sebagai dasar proses dekluster katalog gempa bumi yaitu dengan mengeliminasi gempa bumi yang berada di sekitar gempa bumi berkekuatan besar dalam waktu dan jarak yang tetap.

Langkah awal untuk mengetahui karakteristik kegempaan wilayah Jawa Timur adalah dengan mengeksplorasi kualitas katalog gempa bumi pada wilayah tersebut. Menentukan besarnya parameter seismisitas yang terdiri dari magnitude of completeness (Mc-value), avalue dan $b$-value adalah salah satu bagian dari upaya mengeksplorasi katalog gempa bumi. Sebagian besar, dalam menentukan besarnya parameter seismisitas dari suatu wilayah adalah berdasarkan dari relasi distribusi Gutenberg-Richter. Pada penelitian ini, diguanakan metode Maximum Curvature (MaxC) ${ }^{[10]-[13] .}$ Listing kode dari metode MaxC tersedia secara gratis dalam satu paket perangkat lunak analisis kegempaan yang disebut ZMAP ${ }^{[10]}$, yang ditulis dalam bahasa Matlab. 
MAXC merupakan metode yang dikembangkan oleh Wiemer dan Wyss (2000). Langkah pertama untuk menentukan magnitude of completeness $(\mathrm{Mc})$ adalah dengan menentukan titik MAXC dengan menghitung nilai maksimum turunan pertama kurva frekuensi distribusi magnitudo (FMD) [10], [13], [14]. Korelasi antara frekuensi kejadian gempa bumi dengan distribusi magnitudo gempa bumi dideskripsikan dalam persamaan frekuensi distribusi magnitudo (FMD) sebagai berikut ${ }^{[14]-[16]:}$

$$
\log _{10} N(M)=a-b M
$$

Dimana N(M) adalah frekuensi kejadian gempa bumi dengan magnitudo setara atau lebih besar dari $\mathrm{M}$, pada penelitian ini $\mathrm{M}$ bernilai $\mathrm{Mw} \geq 6.0$, sedangkan $a$ dan $b$ adalah konstanta. Konstanta $a$ disebut juga $a$-value yang mendeskripsikan aktivitas seismik dari wilayah yang diteliti. Konstanta $b$ atau disebut sebagai $b$-value merupakan kemiringan atau slope dari grafik FMD yang merepresentasikan tingkat stress dari batuan di wilayah yang sedang diteliti. Berdasarkan persamaan (1), konstanta $a$ dan $b$ dapat dihitung dengan persamaan sebagai berikut:

$$
\begin{aligned}
& b=\frac{\log _{10}(e)}{\left[\langle M\rangle-\left(M_{c}-\frac{\Delta M}{2}\right)\right]} \\
& a=\log N(M \geq 6,0)+\log (b \ln 10)+(6,0 b)
\end{aligned}
$$

Dimana $\langle\mathrm{M}\rangle$ adalah magnitude rata-rata, $\Delta \mathrm{M}$ adalah rentang bin yang digunakan dalam penelitian, dan Log e: $0.4343^{[14]-[16]}$.

\section{HASIL DAN PEMBAHASAN}

Pada Gambar 2 dan Gambar 3 ditunjukkan kejadian gempa bumi di wilayah Jawa Timur dalam 40 tahun terakhir dari tahun 1980 hingga 2020 dan fluktulasi kenaikan kejadian gempa bumi setiap sepuluh tahun. Pada kedua gambar tersebut sudah mencakup seluruh kejadian gempa bumi besar $(7,0$ - 8,5) Mw, gempa bumi kecil dan sedang $(4,0$ - 6,9) Mw. Kecenderungan kenaikan kejadian gempa bumi dari waktu ke waktu, misalnya pada dekade 1980-1990 yang jumlahnya lebih sedikit (Gambar 2 (a)) apabila dibandingankan dengan gempa bumi yang terjadi pada tahun 2000-2010 (Gambar 2 (c)) menunjukkan apabila teknologi perekaman kejadian gempa bumi mengalami perbaikan yang cukup signifikan. Hal ini ditandai dengan banyaknya titik-titik episenter pada peta seismisitas tersebut, seiring bertambahnya waktu semakin banyak titik-titik episenter gempa bumi.

Dalam kurun waktu empat puluh tahun terakhir, gempa bumi dengan kekuatan kecil sekalipun dapat terekam oleh jaringan seismograf seiring dengan berkembangnya teknologi pencatatan kejadian gempa bumi serta jumlah stasiun seismograf yang tersebar diseluruh dunia. Adanya perkembangan dibidang pencatatan data gempa bumi sangat membantu para peneliti seismologi untuk memperoleh data-data gempa bumi kecil yang terekam dalam beberapa periode sebelumnya. Karena memang sebelumnya hanya gempa bumi-gempa bumi yang berkekuatan besar yang terekam oleh seismograf. Walaupun fokus perhatian kepada gempa bumi berkekuatan besar menjadi yang lebih penting dan utama untuk penelitian kecenderungan gempa bumi karena gempa bumi besar lebih luas secara jangkauan geografis dan kerusakannya lebih besar di permukaan bumi, dan berpeluang besar dan lebih akurat dicatat selama jangka waktu yang lama ${ }^{[4],[5]}$. 

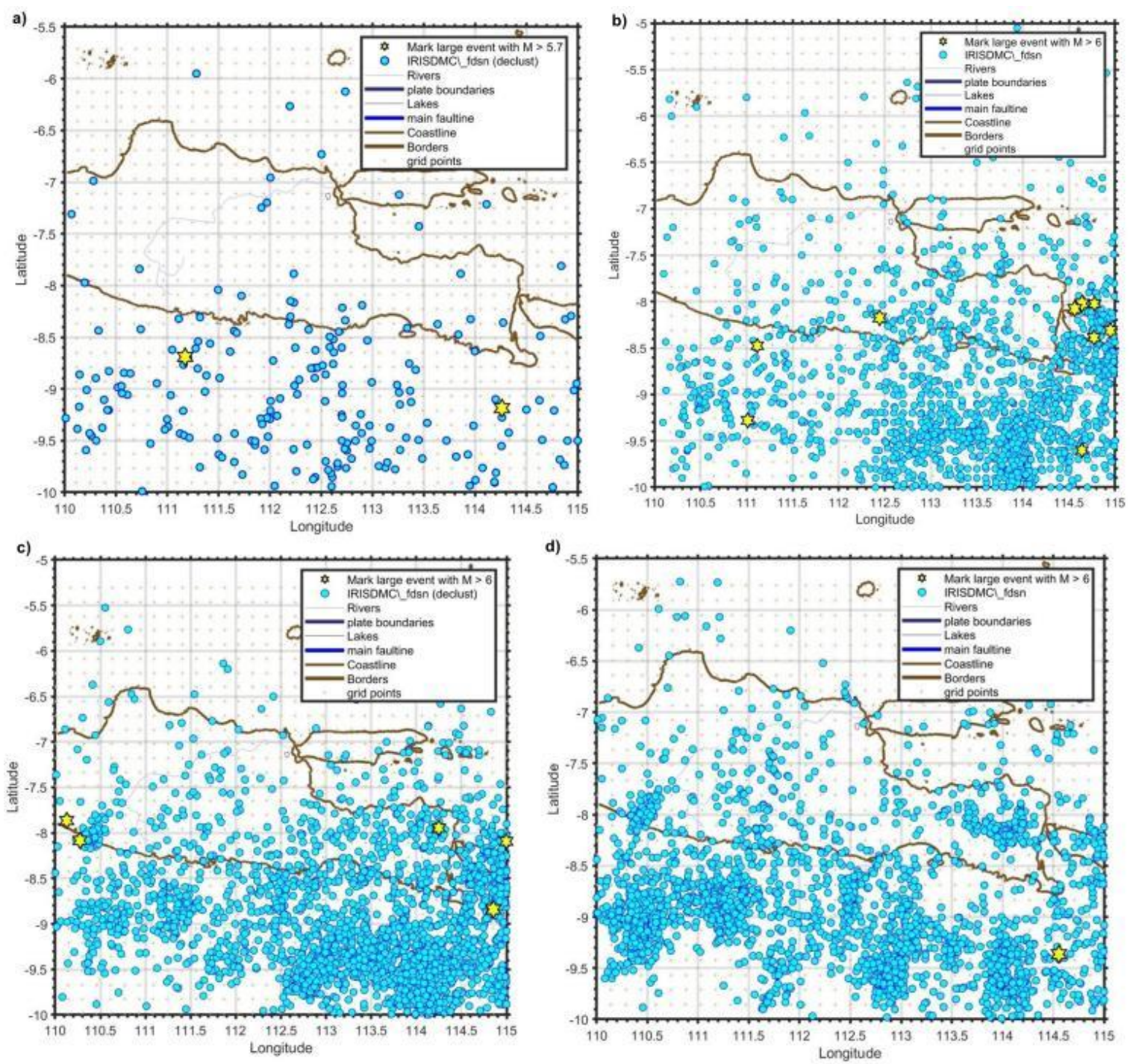

Gambar 2. 2785 kejadian gempa bumi (ditandai dengan simbol lingkaran biru) dan gempa bumi besar (ditandai dengan simbol bintang kuning) yang digunakan dalam penelitian ini berdasarkan katalog gempa bumi ISC dalam kurun waktu 1980-2020, (a) tahun 1980-1990; (b) tahun 19902000; (c) tahun 2000-2010; and (d) tahun 2010-2020.

Kenaikan total keseluruhan gempa bumi selama beberapa periode seperti yang ditunjukkan oleh Gambar 3. Dengan melihat perkembangan jumlah episenter dari periode ke periode dapat ditentukan analisis kecenderungan kejadian gempa bumi. Pada gambar 3 dapat dilihat bahwa tren kejadian gempa bumi semakin meningkat dari tahun ke tahun. Bahkan setelah gempa bumi tahun 1992 tren kejadian gempa bumi semakin meningkat tajam (Gambar 3 (b)). Hal ini diduga akibat dari oleh proses pencapaian keseimbangan stress yang dialami oleh lempeng di bawah permukaan Jawa Timur, sehingga terus menerus terjadi gempa bumi susulan hingga terjadi keseimbangan stress batuan. 
a)

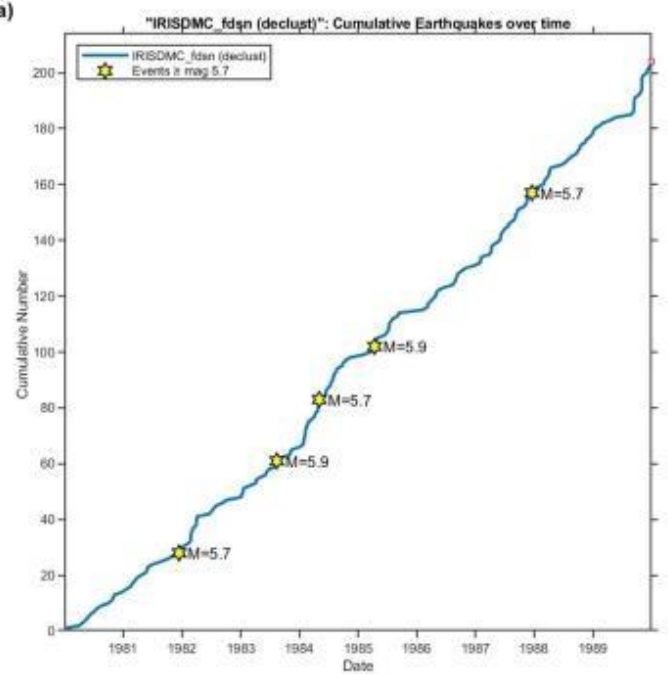

c)

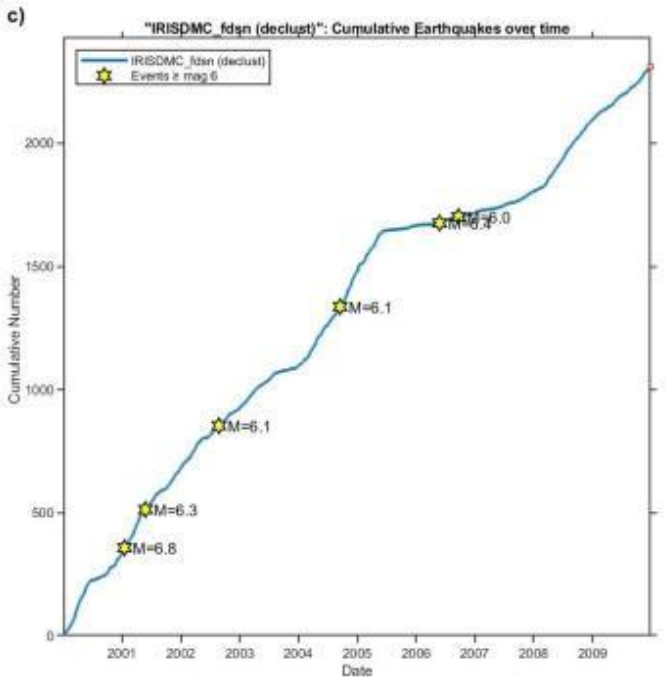

b)

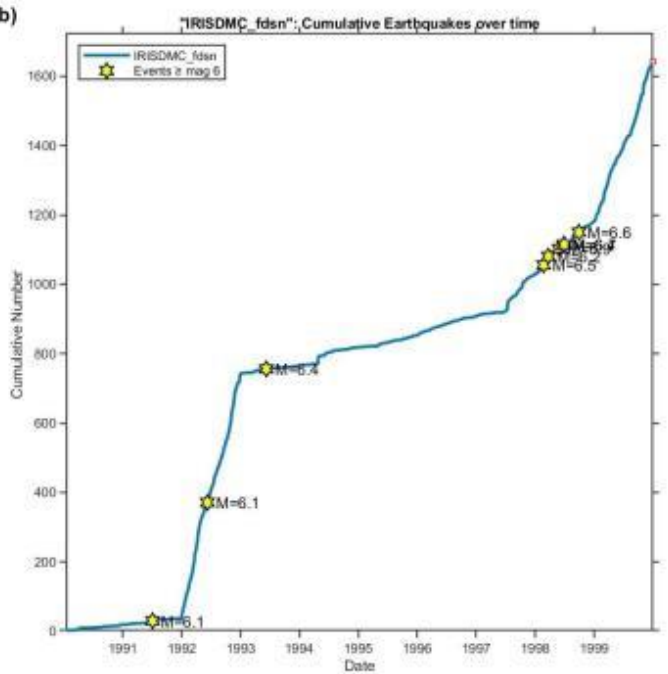

d)

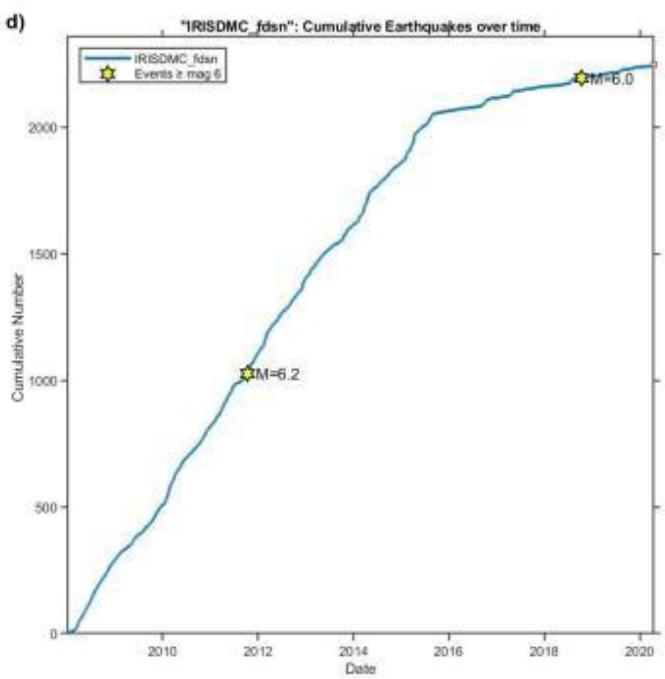

Gambar 3. Grafik Frekuensi kumulatif kejadian gempa bumi dari tahun ketahun setiap dekade dari tahun 1980-2020, (a) 1980-1990; (b) 1990-2000; (c) 2000-2010 dan (d) 2010-2020.

Grafik distribusi frekuensi kejadian gempa bumi terhadap magnitudo (FMD) pada Gambar 4, menjelaskan hubungan magnitudo dan jumlah gempa yang terjadi. Berdasarkan grafik FMD diperoleh nilai magnitude completeness (Mc-value), a-value dan $b$-value dengan cukup akurat dari data observasi dengan mengasumsikan sebuah power-law distribution.

Untuk mengetahui aktivitas seismik dari suatu wilayah atau seismisitas suatu wilayah dapat dilakukan dengan menganalisis grafik hubungan antara frekuensi kejadian gempa bumi dan magnitude (Frequency-Magnitude Disribution, FMD) (Gambar 4). Grafik FMD dari katalog gempa bumi pertama kali diungkapkan oleh Ishimoto dan Iida (1939) dan Gutenber-Ricther (1964). Diungkapkan bahwa grafik FMD menggambarkan hubungan pangkat (power law). Secara umum, b-value mendekati 1, yang berarti 10 kali penurunan aktivitas terkait dengan kenaikan dalam tiap unit magnitudo ${ }^{[17]}$. 

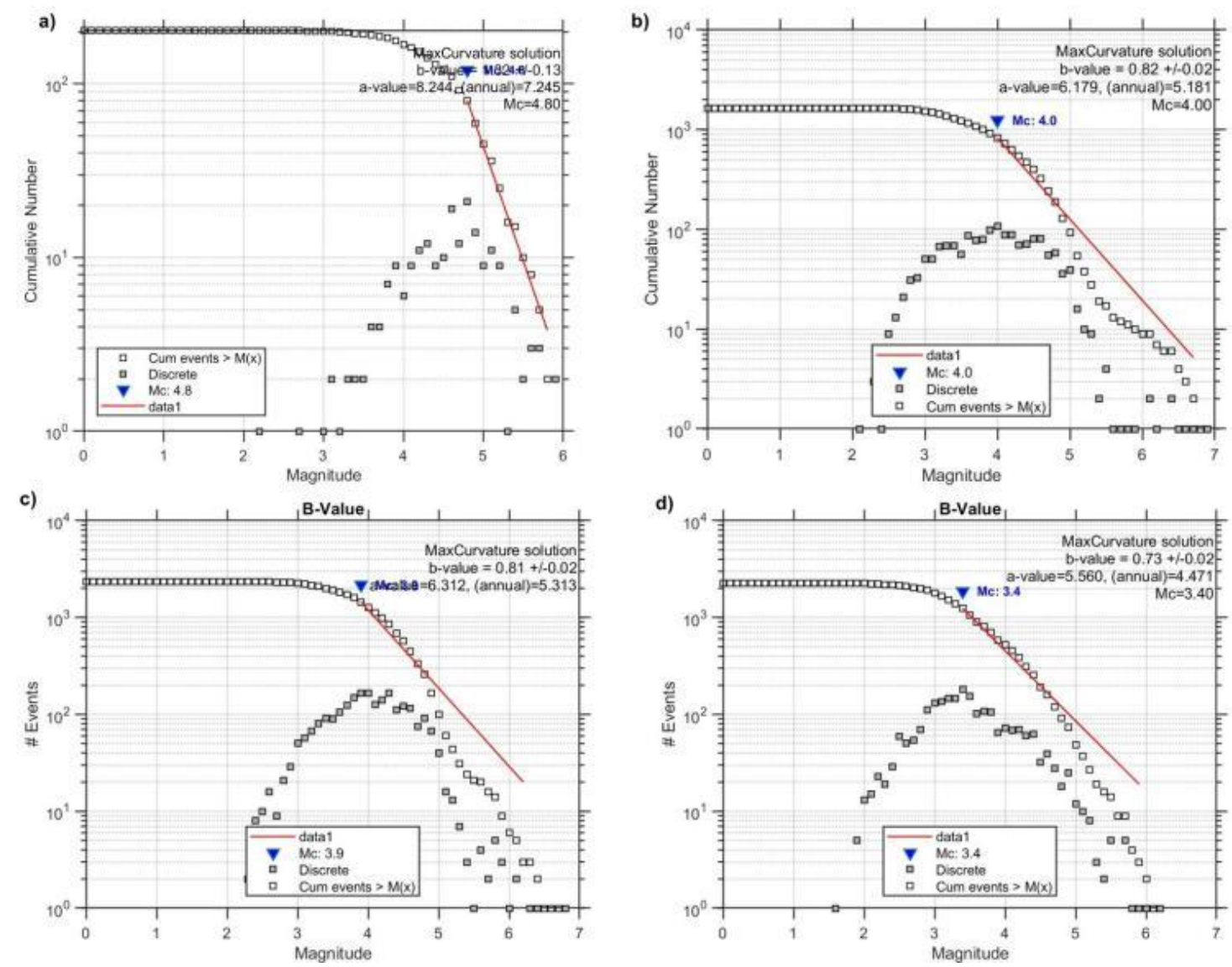

Gambar 4. Grafik Frequency-Magnitude Distribution (FMD) untuk katalog gempa bumi di wialyah Jawa Timur yang terjadi dalam kurun waktu 1980-2020 berdasarkan metode MaxC (a) 1980-1990;(b) 1990-2000; (c) 2000-2010; dan (d) 2010-2020. The best fit dari grafik tersebut ditandai dengan garis solid warna merah dan magnitude of completeness (Mc-value) ditandai dengan simbol segitiga biru. Adapun hasil lengkap dari parameter seismisitas setiap periode dijabarkan pada Tabel 1.

Tabel 1. Besaran Paramater Seismisitas Berdasarkan Analisis Grafik Distribusi Frekuensi-Magnitudo

\begin{tabular}{cccc}
\hline Periode & Mc-value & $a$-value & $b$-value \\
\hline $1980-1990$ & 4,80 & 8,244 & $0,82 \pm 0,13$ \\
$1990-2000$ & 4,00 & 6,179 & $0,82 \pm 0,02$ \\
$2000-2010$ & 3,90 & 6,312 & $0,81 \pm 0,02$ \\
$2010-2020$ & 3,40 & 5,560 & $0,73 \pm 0,02$ \\
\hline
\end{tabular}

Distribusi Mc-value, a-value, dan b-value dalam fungsi waktu (temporal) ini menggambarkan hubungan frekuensi kejadian gempa bumi dengan magnitude dalam fungsi waktu (temporal) yang bertujuan untuk melihat adanya evolusi nilai Mc setiap 10 tahun dari tahun 1980 sampai 2020. Hal ini dapat dilihat pada Tabel 1. Secara rata-rata nilai Mc mengecil selama empat periode terakhir. Hal ini menunjukkan adanya peningkatan kualitas perekaman dan pengolahan data gempa yang dipengaruhi oleh pertambahan jumlah stasiun seismograf yang tersebar diseluruh dunia dan sensitifitas seismograf serta metode yang digunakan ${ }^{[6] \text {. }}$

Beberapa gambar yang ditampilkan berikut ini menunjukkan variasi distribusi spasial dari parameter seismisitas yaitu Mc-value, a-value, dan b-value berdasarkan data katalog 
gempa bumi yang terjadi di Jawa Timur dalam kurun waktu empat puluh tahun terakhir (Gambar 5, Gambar 7, dan Gambar 8).

Hasil pemetaan variasi Mc-value wilayah Jawa Timur untuk katalog gempa bumi ISC dengan menggunakan metoda MaxC dapat dilihat pada Gambar 5(a), 5(b), 5(c) dan 5(d). Dari Gambar 5 (b) terlihat bahwa daerah Jawa Timur bagian utara memiliki nilai Mc yang relatif rendah yaitu berkisar 4,6 - 5 SR. Variasi nilai Mc juga dapat dianalisis berdasarkan posisi stasiun perekam gempa bumi yang digunakan oleh katalog ISC.
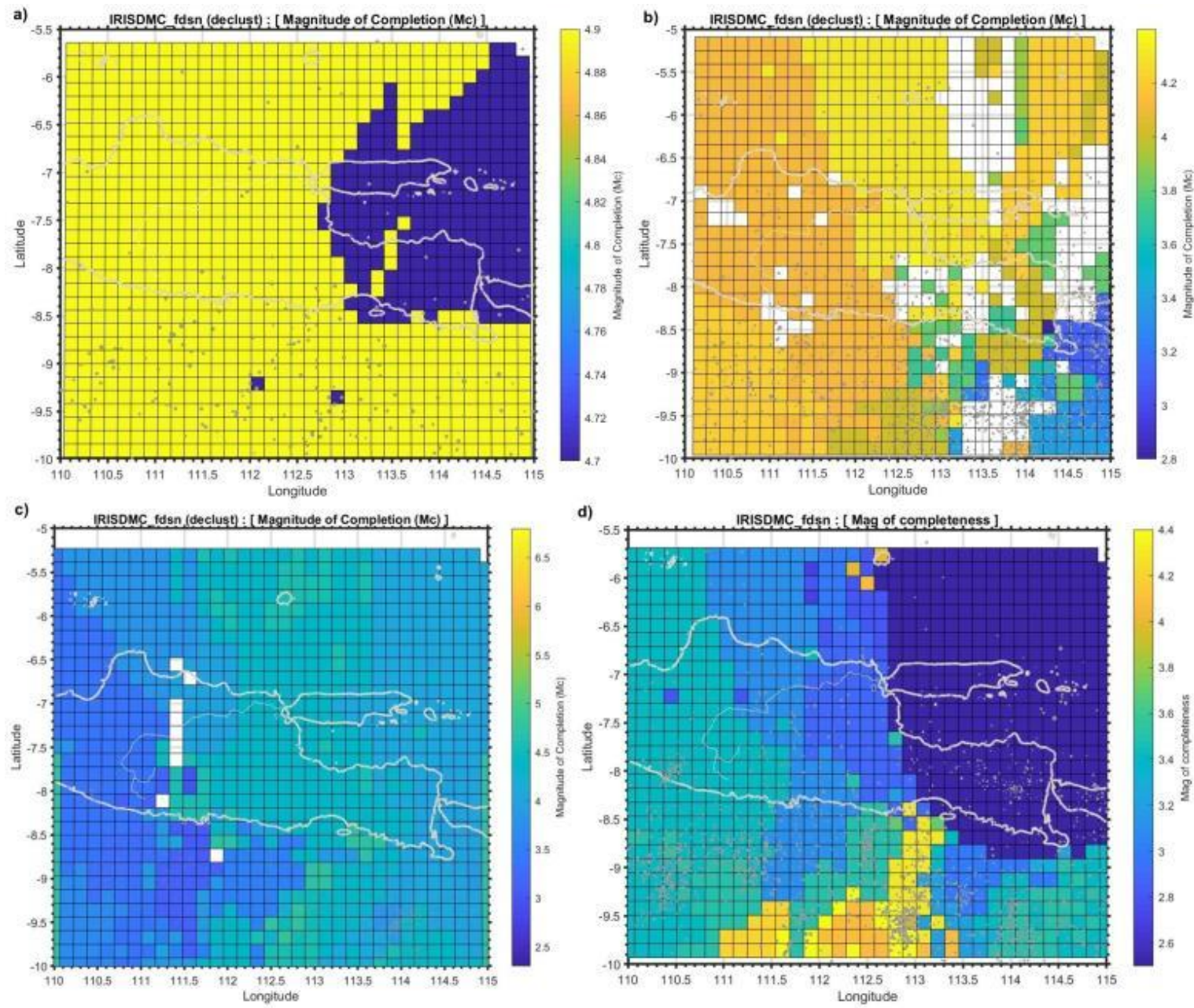

Gambar 5. Variasi distribusi Magnitude of Completeness (Mc-value) di wilayah Jawa Timur berdasarkan katalog gempa bumi ISC dalam empat dekade terakhir (a) 1980-1990; (b) 1990-2000; (c) 20002010 dan (d) 2010-2020.

Terdapat kurang lebih 40 - 45 stasiun perekam gempa bumi yang tersebar di seluruh wilayah Jawa Timur yang mencakup daerah-daerah dengan nilai Mc yang rendah (Gambar 5 dan Gambar 6) (sumber: http://eida.gfz-potsdam.de/webdc3/). Ketersediaan data secara real time dari stasiun perekam gempa bumi setempat juga menjadi salah satu faktor penentu variasi nilai Mc-value. Untuk wilayah bagian selatan dari Jawa Timur pada koordinat -9 ke atas atau masuk ke Laut Jawa diproleh nilai Mc yang cukup tinggi (Gambar 5 (d)) karena pada wilayah tersebut letaknya agak berjauhan dari wilayah Jawa Timur daratan yang mayoritas stasiun perekam gempa bumi tersebut berada (Gambar 6). Hal ini menyebabkan data gempa bumi tidak dapat terekam dengan baik sebagaimana halnya untuk daerah Jawa Timur. 


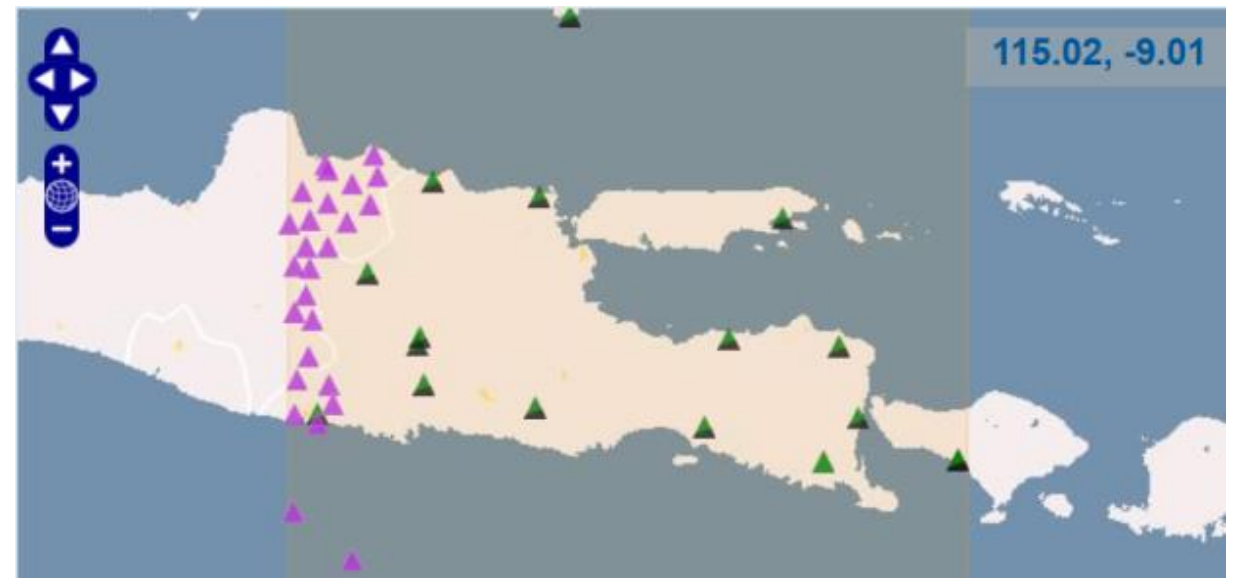

Gambar 6. Sebaran stasiun perekam gempa bumi di wilayah Jawa Timur dan sekitarnya dalam kurun waktu 1980-2020. (sumber: http://eida.gfz-potsdam.de/webdc3/).

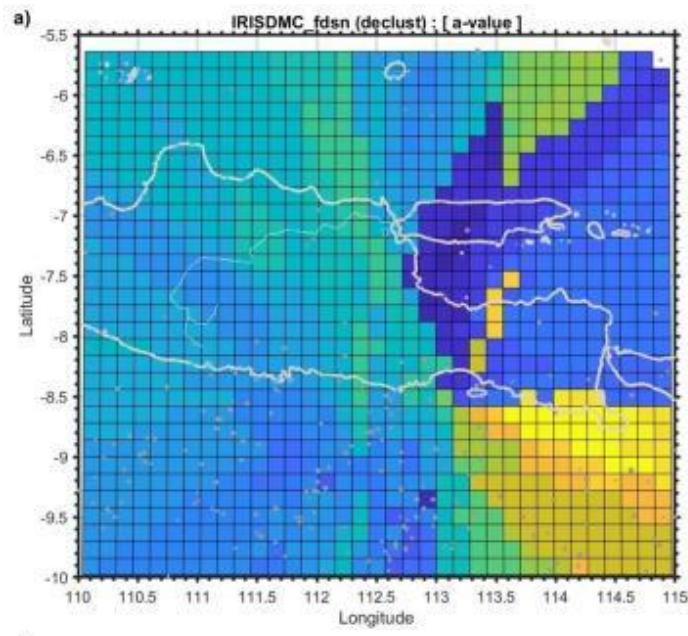

c)

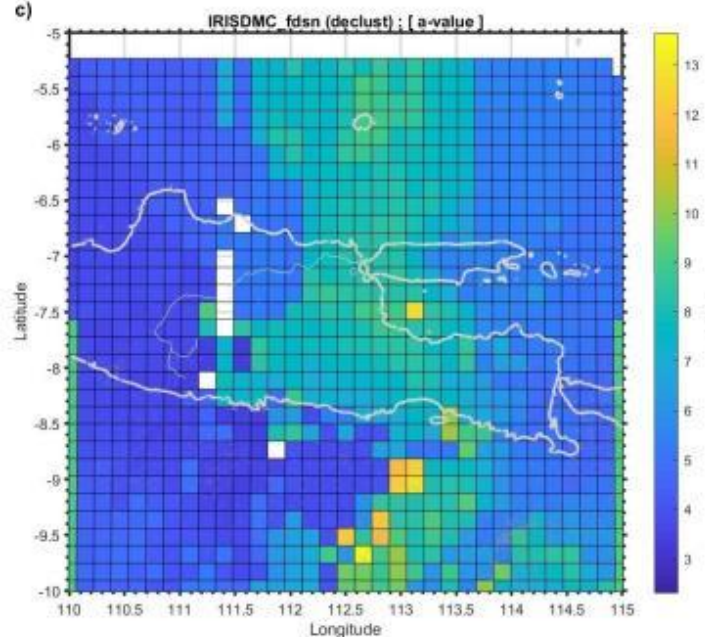

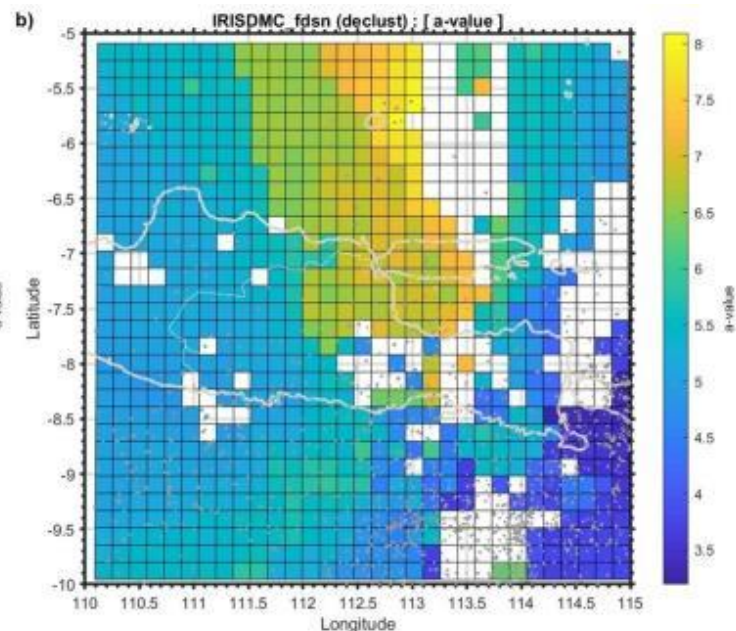

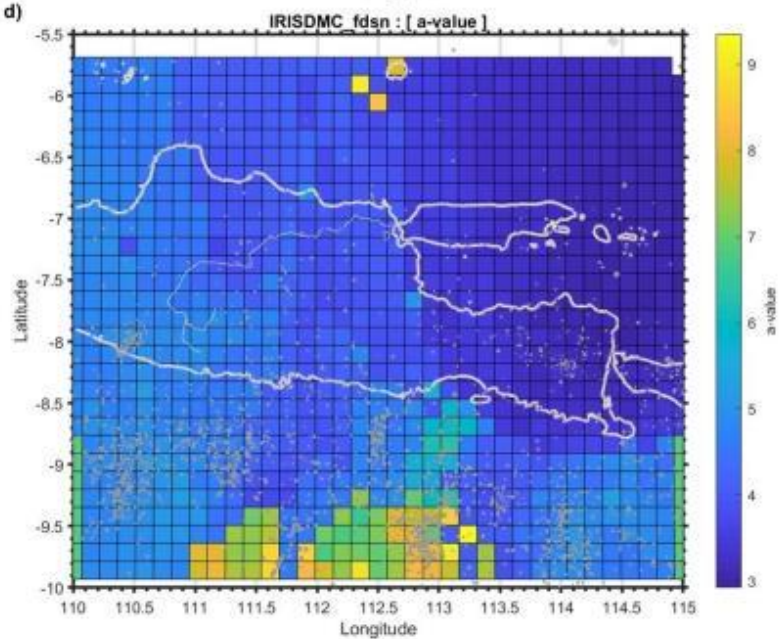

Gambar 7. Variasi distribusi a-value di wilayah Jawa Timur berdasarkan katalog gempa bumi ISC dalam empat dekade terakhir (a) 1980-1990; (b) 1990-2000; (c) 2000-2010 dan (d) 2010-2020.

Hasil pemetaan a-value dapat dilihat pada Gambar 7(a), 7(b), 7(c), dan 7(d), a-value yang rendah terlihat untuk daerah Jawa Timur bagian utara (Gambar 7(d)). Tingkat a-value yang rendah mengindikasikan tingkat frekuensi kegempaan yang rendah namun potensi terjadinya gempa bumi besar cukup tinggi. Hal ini dapat diartikan potensi terjadinya gempa bumi besar akibat dari akumulasi energi yang ada pada wilayah tersebut. Namun 
demikian di wilayah Jawa Timur akumulasi stress tetap tinggi di wilayah aktivitas kegempaan tinggi, hal ini dibuktikan dengan adanya kejadian gempa besar di wilayah dengan $a$-value yang tinggi, yaitu di bagian selatan wilayah Jawa Timur yang merupakan wilayah lautan yang berdekatan dengan batas lempeng tektonik (Gambar 7 (d)). Sebaliknya jika daerah tersebut memiliki a-value yang tinggi maka daerah tersebut memiliki tingkat frekuensi kegempaannya tinggi dengan magnitudo gempa yang relatif rendah.
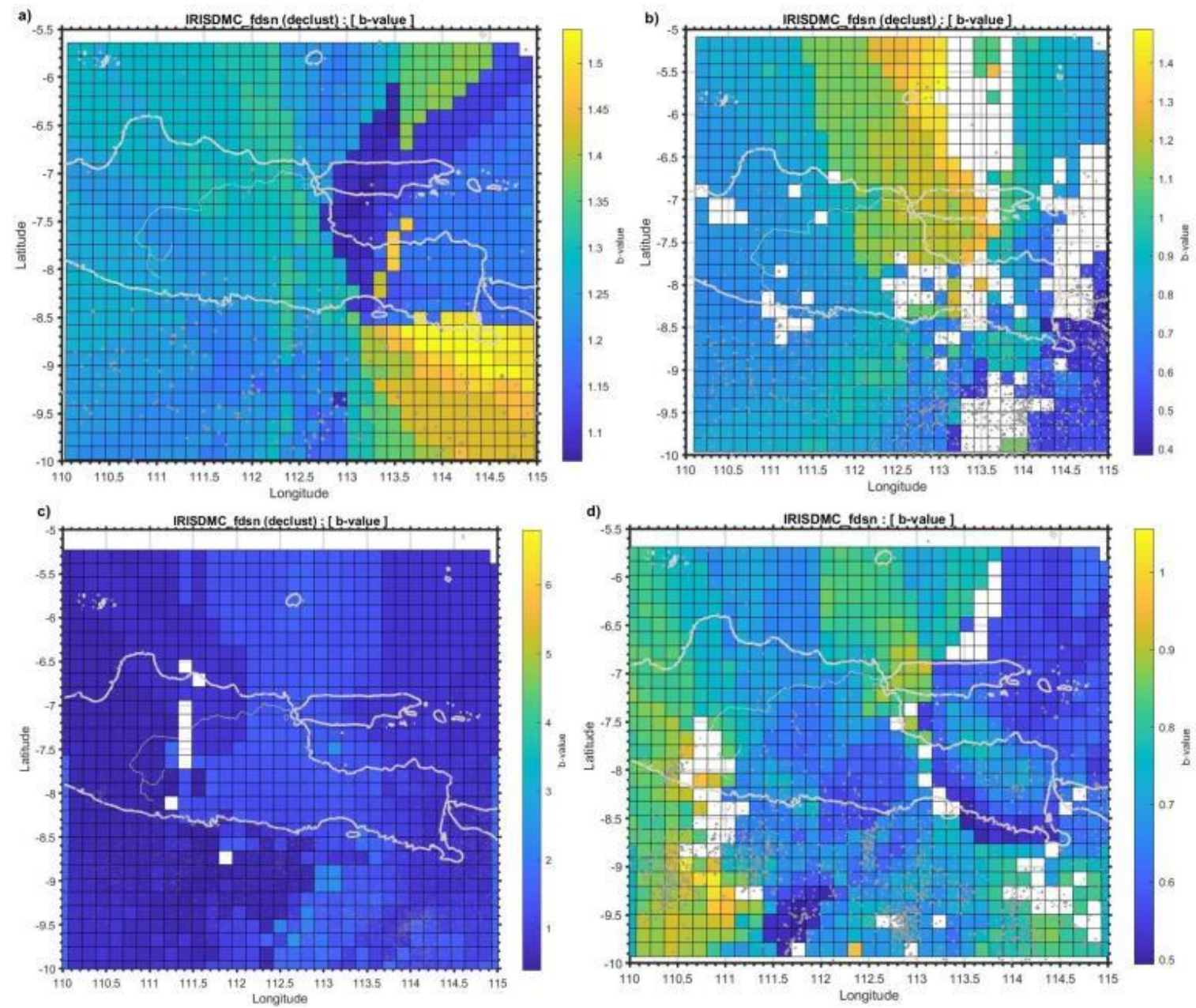

Gambar 8. Variasi distribusi $b$-value di wilayah Jawa Timur berdasarkan katalog gempa bumi ISC dalam empat dekade terakhir (a) 1980-1990; (b) 1990-2000; (c) 2000-2010 dan (d) 2010-2020.

Secara teori $b$-value merupakan parameter seismisitas atau keadaan seismik suatu wilayah yang bergantung kepada sifat batuan bawah permukaan dari wilayah atau area yang diteliti. Semakin tinggi $b$-value dalam suatu wilayah, maka batuan penyusun bawah permukaan wilayah tersebut memiliki tingkat kerapuhan yang tinggi dan daya tahan batuan terhadap stress rendah. Sedangkan apabila suatu wilayah memiliki $b$-value yang kecil berarti tingkat kerapuhan batuannya rendah dan daya tahan batuan terhadap stress besar. Berdasarkan gambar distribusi variasi $b$-value pada periode 1980-1990 (Gambar 8 (a)) warna kuning cenderung hijau yang berada pada wilayah tenggara Jawa Timur yang meliputi wilayah lautan mengindikasikan bahwa wilayah tersebut memiliki $b$-value yang sangat tinggi dibandingkan wilayah lainnya. Hal tersebut seiring dengan berdekatanya wilayah selatan Jawa Timur dengan Java Trench dan batas lempeng di selatan Pulau Jawa yang berkorelasi dengan tingginya aktivitas seismik di wilayah tersebut. Sedangkan $b$ - 
value yang rendah di tandai dengan warna biru muda cenderung ke biru tua, yang bervariasi tersebar mayoritas di wilayah utara Jawa Timur.

Selain itu terdapat wilayah yang tidak dapat dihitung parameter seismisitasnya yang ditandai dengan grid warna putih, baik untuk Mc-value, a-value dan b-value (Gambar 5, Gambar 7, Gambar 8) karena data gempa bumi pada wilayah tersebut terlampau sedikit. Distribusi spasial $a$-value dan $b$-value di wilayah Jawa Timur memiliki pola yang sama, di mana wilayah dengan $b$-value tinggi juga memiliki $a$-value yang tinggi. Nilai mutlak dari parameter seismisitas suatu wilayah sangat bergantung pada akurasi, lamanya periode dan keseragaman katalog gempa bumi yang digunakan, metode perhitungan dan algoritma yang digunakan.

\section{KESIMPULAN}

Parameter seismisitas wilayah Jawa Timur berdasarkan perhitungan metode MaxC didapatkan hasil Mc-value berada pada kisaran 3,4 - 4,8; a-value berkisar 5.560 - 8,244; dan $b$-value $(0.73-0.82 \pm 0.13)$. Kejadian gempa bumi cenderung meningkat selama 40 tahun terakhir. Hal ini tercermin dari penurunan Mc-value dari periode 1980 hingga 2020, yang merupakan parameter kelengkapan gempa bumi terendah yang terekam oleh jaringan seismograf, sehingga diindikasikan adanya peningkatan teknologi pencatatan gempa bumi di wilayah Jawa Timur. Nilai konstanta $b$-value dan $a$-value pada wilayah Jawa Timur tergolong rendah. Hal ini mengindikasikan tingkat stress batuan di bawah permukaan Jawa Timur yang tinggi, sehingga pada wilayah ini berpeluang besar terjadi gempa bumi besar. Namun hasil penelitian ini tidak serta merta dijadikan pedoman mutlak untuk menganalisis tingkat kegempaan di Jawa Timur. Perlu adanya penelitian lebih lanjut dengan membandingkan dengan katalog gempa bumi lain sebagai data pembanding dan metode ataupun algoritma yang digunakan sebagai dasar analisis.

\section{UCAPAN TERIMAKASIH}

Penulis mengucapkan terimakasih kepada Direktorat Riset dan Pengabdian Masyarakat (DRPM) Kemenristek-BRIN yang telah mendanai penelitian ini melalui program hibah Penelitian Dosen Pemula (PDP) tahun pendanaan 2020 dengan kontrak No: 083/SP2H/LT/DRPM/2020 tertanggal 9 Maret 2019. Kami juga mengucapkan terimakasih kepada ISC (Incorporated Research Institutions for Seismology and the International Seismological Center) yang terus menyediakan mengupdate katalog gempa bumi serta kepada ZMAP yang telah menyediakan freeware implementasi statistika seismologi. 


\section{DAFTAR PUSTAKA}

1 McCaffrey, R. 2009. The Tectonic Framework of the Sumatran Subduction Zone Annu. Rev. Earth Planet. Sci., 37(1), 345-366. doi: 10.1146/annurev.earth.031208.100212.

2 Gui, Z., Bai, Y., Wang, Z. and Li, T. 2019. Seismic b-value anomalies in the Sumatran region: Seismotectonic implications. J. Asian Earth Sci.,173, no. January, 29-41. doi: 10.1016/j.jseaes.2019.01.015.

3 Prawirodirdjo L and Bock, Y. 2004. Instantaneous global plate motion model from 12 years of continuous GPS observations. J. Geophys. Res. Solid Earth, 109 (8), 1-15 doi: 10.1029/2003JB002944.

4 Madlazim, M. 2013. Kajian Awal Tentang B Value Gempa Bumi Di Sumatra. J. Penelit. Fis. dan Apl., 3 (1), 41. doi: 10.26740/jpfa.v3n1.p41-46.

5 Shohaya, J.N., Chasanah, U., Mutiarani, A., Wahyuni, L.P., and Madlazim, M. 2013. Survey Dan Analisis Seismisitas Wilayah Jawa Timur Berdasarkan Data Gempa Bumi Periode 1999-2013 Sebagai Upaya Mitigasi Bencana Gempa Bumi. J. Penelit. Fis. dan Apl., 3 (2), 18. doi: 10.26740/jpfa.v3n2.p18-27.

6 Gunawan, E., and Widiyantoro, S. 2019. Active tectonic deformation in Java, Indonesia inferred from a GPS-derived strain rate. J. Geodyn., 123, 49-54. doi: 10.1016/j.jog.2019.01.004.

7 Bilek, S.L., and Engdahl, E.R. 2007. Rupture characterization and aftershock relocations for the 1994 and 2006 tsunami earthquakes in the Java subduction zone. Geophys. Res. Lett., 34 (20), 1-5. doi: 10.1029/2007GL031357.

8 Koulali, A., Mcclusky, S., Cummins, P., and Tregoning, P. 2018. Wedge geometry, frictional properties and interseismic coupling of the Java megathrust Tectonophysics. doi: 10.1016/j.tecto.2018.03.012.

9 Huang, H., Meng, L., Bürgmann, R., Wang, W., and Wang, K. 2020. Spatio-temporal foreshock evolution of the 2019 M 6.4 and M 7.1 Ridgecrest, California earthquakes. Earth Planet. Sci. Lett., 551, 116582. doi: 10.1016/j.epsl.2020.116582.

10 Wyss, W., Wiemer, S., and Zúñiga, R. 2001. Zmap A Tool For Analyses Of Seismicity Patterns Typical Applications And Uses : A Cookbook Table of Content. Writing, 6401.

11 Pramono, S., Prakoso, W.A., Rohadi, S., Karnawati, D., Santoso, E., and Nurfajar, A. 2020. Influence of seismicity declustering on ground motion prediction equations for central sulawesi seismic region. Int. J. GEOMATE, 19, (71), 61-68. doi: 10.21660/2020.71.28369.

12 Baranov, S.V., Shebalin, P.N., and Gabsatarova, I.P. 2019. Relationship between preceding seismicity and the probability of strong aftershock occurrence. Geophys. Res., 20 (3), 5-19. doi: 10.21455/gr2019.3-1.

13 Leptokaropoulos, K.M., Karakostas, V.G., Papadimitriou, E.E., Adamaki, A.K., Tan, O., and Inan, S. 2013. A homogeneous earthquake catalog for western Turkey and magnitude of completeness determination. Bull. Seismol. Soc. Am., 103 (5), 27392751, doi: $10.1785 / 0120120174$.

14 H. E. A. Hafiez, H.E.A. and Toni, M. 2020. Magnitude of completeness for the Northern stations of the Egyptian National Seismological Network. Arab. J. Geosci., 13(12), 1-9. doi: 10.1007/s12517-020-05461-0.

15 Radziminovich, N.A, Miroshnichenko, A.I. and Zuev, F.L. 2019. Magnitude of completeness, b-value, and spatial correlation dimension of earthquakes in the South 
Baikal Basin, Baikal Rift System. Tectonophysics, 759, no. April, 44-57. doi: 10.1016/j.tecto.2019.04.002.

16 Woessner, J. and Wiemer, S. 2005. Assessing the quality of earthquake catalogues: Estimating the magnitude of completeness and its uncertainty. Bull. Seismol. Soc. Am., 95 (2), 684-698. doi: 10.1785/0120040007.

17 H. E. A. Hafiez, H.E.A. 2015. Estimating the magnitude of completeness for assessing the quality of earthquake catalogue of the ENSN, Egypt. Arab. J. Geosci., 8 (11), 9315-9323. doi: 10.1007/s12517-015-1929-x. 